\title{
Issues in the quantitative analysis of the SIPRI arms industry database
}

\section{Ron Smith and J. Paul Dunne}

Ron Smith is Professor of Economics, Birkbeck College, University of London, London, United Kingdom. The corresponding author, he may be reached at r.smith@bbk.ac.uk. J. Paul Dunne is Professor of Economics, School of Economics, University of Cape Town, Cape Town, South Africa. He may be reached at john.dunne@uct.ac.za.

\section{Abstract}

Although the Stockholm International Peace Research Institute's data on the 100 largest arms (and military services) producing firms is very widely used for various purposes, there is relatively little quantitative statistical analysis of it. This article discusses some of the issues involved in the econometric analysis of the data. This is complicated by the difficulty of modeling the processes of mergers, acquisitions, and divestments which drives entry and exit from the list. Various models are estimated to examine (a) the relationship between arms sales and military expenditure, (b) the evolution of concentration and the size distribution of firms, (c) the cross-section relationship between size and growth of firms, (d) the times-series properties of the arms sales of individual firms, and (e) of arms sales by country of ownership.

$\mathrm{A}^{\mathrm{s}}$ lthough the Stockholm International Peace Research Institute's (SIPRI) data on the 100 largest arms (and military services) producing firms is very widely used for various purposes, there is relatively little quantitative statistical analysis of this arms industry data. This contrasts with the vast number of econometric studies using the numbers from the SIPRI military expenditure and arms trade databases. This article will discuss some of the issues involved in the econometric analysis of the arms industry data, suggesting topics worth investigating and linking the analysis of the arms industry to more general approaches in industrial economics. In the process it will discuss potential models and provide some exploratory data analysis and preliminary estimates. Hartley (2017) provides a recent review of the economics of the arms industry.

We first discuss the relationship between the data available on military expenditure, the arms trade, and arms sales by firms. This relationship is complicated by differences in definition and valuation and by lack of information about a crucial intervening variable: domestic arms production. ${ }^{1} \mathrm{We}$ also discuss some definitional issues and practical problems. While there is extensive qualitative work on this topic, quantitative work is complicated by the need to model entry and exit from the list of arms firms as a result of mergers, acquisitions, and divestments. ${ }^{2}$

We then consider some possible research questions. These include the relationship between arms sales and military expenditure, concentration in the arms industry and the size distribution of firms, the patterns of growth by the individual companies over time, and the growth in sales by country of ownership. Finally, we make some concluding comments.

\section{Relationships among the SIPRI databases}

SIPRI provides data on military expenditure, the arms trade (imports and exports of arms), and arms sales by the world's top-100 arms companies. In principle, these are all related. In practice, a number of problems arise in linking them, which are reviewed below. The other major data source is World Military Expenditures and Arms Transfers (WMEAT), which until 1999 was published by the U.S. Arms Control and Disarmament Agency (ACDA), and subsequently by the U.S. Department of State. It does not include data on arms sales by companies but does include data on the number of people in the armed forces.

Ignore, for now, the practical problems and consider what identities would hold supposing we had perfect data. Military expenditure in a particular country is made up of procurement of domestically produced and imported arms, plus other components of military expenditure such as the salaries of the armed forces.

National arms production equals the amount of domestic procurement by the national government plus the sum of arms exports to other countries. Since exports from country $i$ to $j$ equal imports to $j$ from $i$, world exports equal world imports. A firm's total arms sales is the sum of what its subsidiaries in each other country sell for domestic procurement in that country, sell to other arms companies as inputs, and sell for export from that country. If Rolls-Royce sells engines to BAE who then sells the aircraft containing the engines, the engines are counted twice, once in Rolls-Royce sales and once in BAE sales. This complicates the interpretation.

We do not observe arms production or sales in a particular country, nor intermediate inputs. In principle, input-output tables allow the measurement of value added, the proportion of 
turnover accounted for by intermediate inputs, sales to other companies, and final demand for domestic procurement or exports. But the standard industrial classification used in input-output tables does not have categories that capture total arms production. Not only are exports and imports of weapons components between companies difficult to capture, but also the valuation of international intra-company transactions, such as supply of components between two subsidiaries, is complicated by the transfer pricing policies of the companies, which may reflect tax avoidance or other factors.

In practice, then, the identities do not hold, not even for nonmilitary production. For instance, because of measurement errors world imports are not equal to world exports. The problem is compounded in that the three types of data (military expenditure, arms production, arms trade) come from quite different sources. Military expenditure data ultimately are derived from government budget data, the arms trade data are based on reports of physical transfers, and the arms sales data come from company accounts and measure turnover rather than value added. There are different valuation procedures (current or constant prices, which currency is used, etc.) and different definitions of what constitutes "military" among the three types of data. Since the data are given in U.S. dollars, movements in exchange rates against the dollar can make a large difference.

\section{Definitions of the arms industry}

A major difficulty is that arms is not a category in any of the standard lists, such as the Harmonized Commodity Description and Coding System of the World Customs Organization, the UN Standard International Trade Classification, SITC, or the International Standard Industrial Classification, ISIC. In ISIC Revision 4 there are categories-Weapons and Ammunition (ISIC2520; in Rev. 3 it was 2927), Military Fighting Vehicles (ISIC3040), and Defense Activities (ISIC8422)—which cover the operation of the military. But both military and civilian items are included in many of the relevant categories, such as aerospace and electronic equipment.

For military expenditure SIPRI uses government definitions. Although NATO tries to establish common reporting categories, in practice there is considerable flexibility in what governments report. Definitional changes, such as the removal of paramilitary forces from the NATO definition, agreed in 2004, cause structural breaks, particularly since different countries revised their definitions at different dates. Sometimes the figure may be a budgeted number rather than actual outlays. The degree of disaggregation of the total differs, and although for NATO countries one can also get data on procurement expenditure on equipment, there are questions about its reliability and whether definitions are consistent
This article discusses some of the issues involved in the econometric analysis of arms industry data. Various models are estimated to examine (a) the relationship between arms sales and military expenditure, (b) the evolution of concentration and the size distribution of firms, (c) the cross-section relationship between size and growth of firms, (d) the times-series properties of the sales of individual firms, and (e) of arms sales by country of ownership.

across countries. There are also inevitable currency conversion issues. Smith (2017) discusses the measurement of military expenditure.

For arms transfers SIPRI construct a volume measure of transfers of major weapons systems valued using trend indicators. WMEAT has a wider definition and refers to the value of the goods and services actually delivered, although the price actually paid can be difficult to determine. Some studies have examined the use of the ratio of the WMEAT to SIPRI measures to provide an implicit price index, e.g., Smith and Tasiran (2010). Most export licensing systems are designed to approve or prohibit particular transfers and are not designed to capture data on the volume and value of trade. Other reported data might relate to orders, deliveries, or payments and these can differ substantially because some orders are cancelled and some deliveries are never paid for. Given how complicated international arms transfers are, with offsets, countertrade, aid, concessionary finance, servicing, and training, it is often difficult to know how to define an appropriate price or interpret the reported numbers for the value of a contract.

For the list of the largest 100 arms producing firms, SIPRI uses data that come largely from company accounts. What is counted as arms production probably differs considerably between firms. ${ }^{3}$

Firms differ in the amount of information they provide on where the sales are made and where the production takes place. Although the arms industry is less multinational than many other industries, it is still globalized, particularly through components. Whereas military expenditure and arms transfers have global coverage, the arms company data is missing data on Chinese firms that are now an increasing proportion of the market. As noted, looking at total arms sales by companies involves some double-counting since they sell military components to each other.

\section{Domestic production}

The biggest gap in the data is that there is virtually no direct data on domestic production of arms. In principle, countries should have estimates of the size of their defense industrial bases for procurement planning purposes. However, in many 
cases the defense ministry may not know where the production is coming from. It may procure from a domestic firm that assembles the weapons from components sourced from all over the world and if those components are dual use, they will not be counted in arms imports figures. Often the arguments about the defense industrial base are political. Firms emphasize how many jobs a military contract will generate when lobbying for it. This adds more noise into the figures. Countries also differ in whether they define their defense industrial base on the basis of ownership by nationals or the national location of production, irrespective of ownership. One could try to estimate domestic production, for NATO countries where spending on equipment is available, as being procurement of defense equipment plus exports minus imports. But the measurement errors are likely to be large, because of definitional and valuation differences, although there may be statistical ways to reduce the noise in the series. A theoretical model of the defense industrial base which links the elements discussed above is provided in Dunne, et al. (2007).

\section{The data analyzed}

The analysis that follows uses the arms industry database spreadsheet as retrieved from SIPRI's website. Within it, each sheet is for a year and gives in column $\mathrm{A}$, the rank for that year; $\mathrm{B}$, the rank in the previous year; $\mathrm{C}$, company name; $\mathrm{D}$, notes; E, country; F, arms sales; G, arms sales in constant prices; H, total sales; I, arms sales as a percent of total sales; J, total profit; and $\mathrm{K}$, total employment. There is a separate spreadsheet setting out total sales over all top-100 companies for each year, at current and constant prices.

Companies are ranked according to the value of their arms sales at the end of their financial year. Figures for subsidiary companies, where available, are given together with the name of the parent company, although subsidiaries are not included in the ranking. Company names and structures are listed as they were at the end of the financial year. The notes list information about subsequent changes, e.g., when Lockheed Martin acquired helicopter producer Sikorsky from United Technologies in 2015, and explanations of major revisions. When there is a lot of uncertainty attached to an estimate this is also noted. The notes are more detailed for more recent years. In the past SIPRI gave data for the sectors that the companies operated in, but this is no longer given. Allocating companies to sectors can be difficult for many of the companies which are highly diversified conglomerates. There has been a major growth in military service companies over the years (Dunne and Smith, 2016).
Table 1: Arms sales and military expenditures

$\begin{array}{lll}\text { Dependent variable: D(LAS) sample, 2003-2016 } \\ \text { Variable } & \text { Coefficient } & \text { Std. error } \\ \text { C } & -0.474416 & 0.155104 \\ \text { D(LMELC) } & 1.555025 & 0.143426 \\ \text { Z(-1) } & 0.349445 & 0.116098 \\ & & \\ \text { R-squared } & 0.917374 & \\ \text { Adj. R-squared } & 0.902351 & \\ \text { S.E. of regression } & 0.015956 & \end{array}$

The relationships of arms sales to military expenditure There is clearly scope for more work on the empirical relationship among the three types of variables: military expenditure for individual countries, arms exports and imports, and the sales by countries' arms firms. On the demand side, high military expenditure may suck in imports (see Smith and Tasiran, 2010) or may boost sales of the national arms firms, and this might help them to export. The latter link, through the sales of domestic arms firms, does not seem to have been investigated. Some arms firms like Airbus are not national, but their sales could be allocated to the owning nations. However, there would be jumps in sales by a country's firms when there was a cross-national takeover.

As a crude example of this sort of analysis, consider the ratio between world arms sales and world military expenditure, both in constant 2015 U.S. dollars, over the period 2002-16. This ratio averages about 25 percent. As noted already, military expenditure includes things other than expenditure on arms, including wages for the military, and the total sales of the arms companies involves some double-counting. Over the period, real military expenditure grew about 45 percent and real arms sales 38 percent. Since the arms sales figures exclude China we used world military expenditure less China. The estimated error correction model made the change in log arms sales, $\mathrm{D}(\mathrm{LAS})$, a function of the change in log military expenditure less China, D(LMELC), and the lagged difference between log military expenditure less China and $\log$ arms sales: $\mathrm{Z}=\mathrm{LMELC}-\mathrm{LAS}$. The results are given in Table 1 .

The short-run elasticity of arms sales to military expenditure is 1.56 , the long-run elasticity is constrained to be one (the $t$-value testing the hypothesis of a unit coefficient was 1.1), and the speed of adjustment is 35 percent a year. The fit is quite good: an average error of 1.6 percent, and 92 percent of the growth in arms sales explained by military expenditure. 

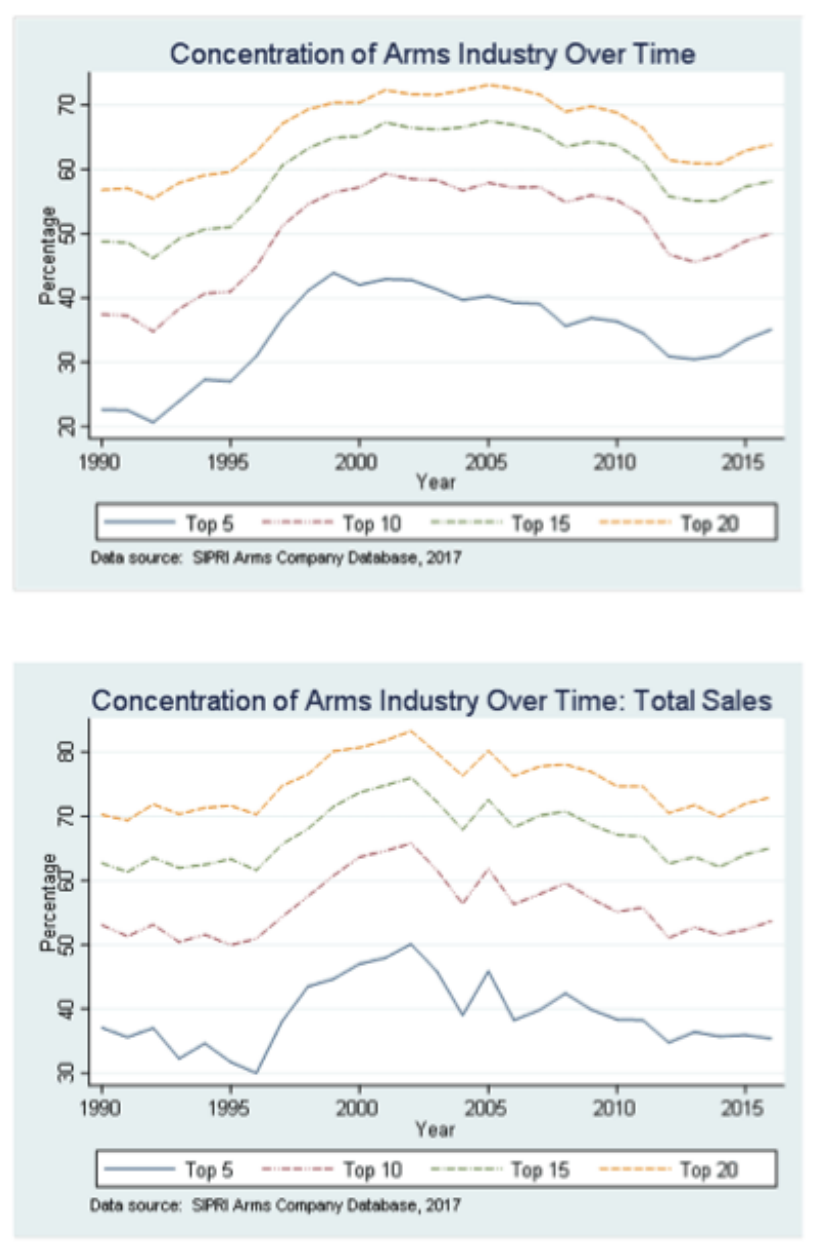

Figure 1: Concentration ratios for the SIPRI top-100 arms firms. Top panel: Arms sales only. Bottom panel: All sales, including arms sales.

Using world military expenditure including China gave a very similar fit, with an R-squared of 0.913 . Given that the two series are apparently independently constructed, the similarity between them is quite striking. This is, of course, a very short time series and structural changes may cause the relationship to change. Similar equations could be estimated for the total arms sales of the companies located in individual countries to examine the relationship with military expenditure and exports of that country.

Concentration and the size distribution of firms An example of the quantitative analysis of the SIPRI arms industry data is Dunne and Smith (2016), which examines the evolution of concentration in the global arms industry over the period 1990-2013. The market share of the top-5 firms, C5, went up from 22 percent in 1990 to a peak of 43 percent in

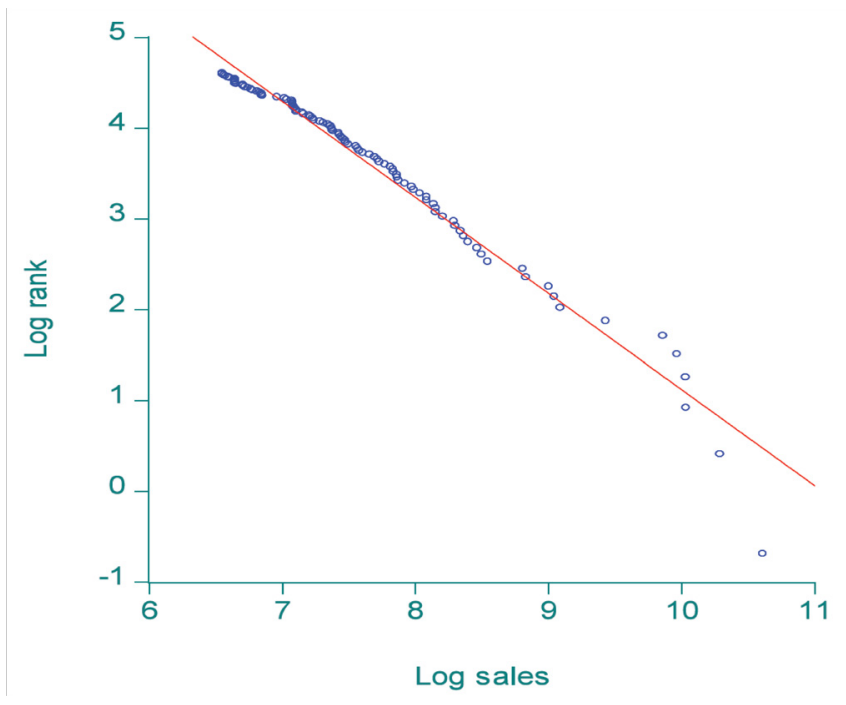

Figure 2: Plot of log rank against log sales for SIPRI top100 arms firms, 2016.

1999 before declining to 35 percent by 2011. Using revised data, the 5 -firm concentration ratio was 45 percent in 2002 , falling to a low of 33 percent in 2014, then rising to 37 percent in 2016. The top panel in Figure 1 shows the concentration of arms sales for differing numbers of firms, which show a similar pattern to $\mathrm{C} 5$, albeit on different vertical scales. The global arms industry is less concentrated than comparable civilian industries. In fact, the size distribution of arms sales by these firms is less concentrated (top panel) than the total sales of the same companies as shown in the bottom panel of Figure 1.

Real arms sales peaked in 2010, then fell until 2015, rising again in 2016. There is some negative relationship between sales and concentration - falling sales prompt concentrationbut it is not close. Dunne and Smith (2016) concluded: "What is clear is that there are economic forces pushing for increased competition, but the final outcome will be determined by political forces, and transparency and governance will become increasingly important issues."

An alternative way to examine the size distribution of firms is to see whether the industry follows the usual power law. This involves a plot of the log rank against log arms sales. This shows how sales decline with firm rank. Power laws or Pareto Distributions occur in many phenomena such as the size of wars, cities, businesses, income, or wealth. The graph for 2016 is given in Figure 2.

Relative to the graphs shown in Dunne and Smith (2016), there are larger positive errors, i.e., more firms larger than one would expect, for values of log size between 9 and 10. For values of $\log$ size above 10 , there is the same pattern of negative errors that they noted. Sales tend to be lower at the 
Table 2: Pareto regression of log rank minus a half on log size

\begin{tabular}{|c|c|}
\hline Variable & Coefficient \\
\hline $\mathrm{C}$ & 11.68888 \\
\hline Log sales & -1.056655 \\
\hline R-squared & 0.971235 \\
\hline Adj. R-squared & 0.970942 \\
\hline S.E. of regression & 0.167848 \\
\hline Durbin-Watson stat. & 0.368271 \\
\hline
\end{tabular}

very top relative to what would be predicted. This pattern is also present in power law graphs for all firms, but is more marked for arms firms.

This distribution can be summarized using a Power Law regression. The relationship between rank, $R$, and size, $S$, can be written: $R=A X^{-b}$. A special case is Zipf's law, where $b=1$, coming from linguist Zipf's observation that the frequency of any word is in proportion to its rank in the frequency table. So the most frequent occurs twice as often as the second most frequent, and so on. This does seem to work well for the distribution of firm size, but there is a downward bias on estimation, which has been dealt with by using the half correction and estimating a regression of $\log ($ Rank $-1 / 2)$ on a constant and log size.

If $b=|1|$ then the distribution fits the Zipf. If $b>|1|$ there is a tendency for concentration to larger firms and if $b<|1|$ there is a tendency for concentration to smaller firms. For nondefense firms the size distribution tends to follow the distribution with an exponent of about |1.06|. Dunne and Smith (2016) found that there was a clear change in the coefficient value from above one to below it, with the transition taking place in the early 2000s. Then, in the late 2000s, it rises again and is close to 1 by 2011. It has continued rising toward more concentration and is $|1.06|$ in 2016 , as shown in Table 2.

Growth by company

Using cross-section information, one can regress the growth of firms over a period on the logarithm of initial size and other characteristics, such as nationality or the sectors they operate in. Gibrat's law says that growth is independent of initial size and whether this holds is an interesting question. As a crude example consider growth over the five year period 2011-16. Matching companies, in some cases with different names, gave

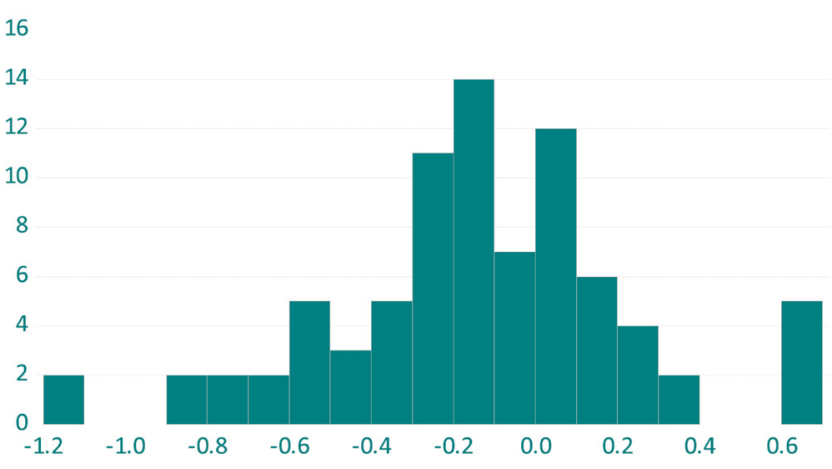

Figure 3: Distribution of continuing company growth rates (change in logarithm), 2011-6.

a sample of 82 firms. The length of the period over which one measures the growth rate will determine the size of the sample. Because firms enter and exit the top-100, the longer the period the fewer continuing firms there will be. ${ }^{4}$ The simple histogram for the change in the logarithm of current sales is shown in Figure 3.

The hypothesis that the distribution is normal is not rejected on a skewness-kurtosis test (skewness $=-0.16$; kurtosis $=3.72$; Jarque-Bera $=2.11 ; p$-value $=0.35)$. Both the mean and median decline by 14 percent, but the range is massive ( -1.17 to 0.70$)$ and, at 0.37 , the standard deviation is well over twice the mean. Starting from 12 country dummies, there seemed to be little difference between countries, except that Russian firms and firms from non-Japanese Asian countries grew faster than the others. The growth by Russian firms is partly the result of the creation of holding companies, such as United Aircraft, many of whose constituents were not in the top-100 before.

Neither the share of arms in total sales ${ }^{5}$ nor log arms sales in 2011 were significant. This suggests that Gibrat's Law, that growth is independent of size, holds. However, there seemed to be a nonlinearity in log initial size and when its square was added to an equation, also including dummies for other Asian and Russian companies, it was significant, giving a U-shaped relationship with a minimum at arms sales of USD5.7 billion, which was around rank 13. Firms bigger and smaller than that size grew significantly faster, but there is a lot of noise in the relationship. Adding the squared term increased the adjusted Rsquared from 0.19 to 0.26 . The equation does not fit well, explaining a small proportion of the variation in growth. There are two outliers close to the minimum which have the largest negative growth rates, less than minus one. These are two U.S. firms, Science Applications International Corp., ranked 12 in 2011, which divested Leidos, and Oshkosh, ranked 17 in 2011, which suffered from a decline in demand for armored vehicles 
with the reduction of U.S. troops in Iraq and Afghanistan. However, when dummy variables were added for these two firms, log initial size and its square remain significant, both jointly and individually. Adding the two dummies increases the adjusted Rsquared to 0.38 and reduces the $t$ statistics of log initial size from -2.89 to -2.53 and of its square from 2.81 to 2.48; both still significant. ${ }^{6}$ The implied minimum, at USD5.4 billion, is very similar. It would be interesting to see if the U-shape relation held in earlier years as well.

\section{Time series for firms}

The quantitative time-series analysis of the development of individual firms over time is problematic because of the prevalence of mergers, acquisitions, and divestments. This is a general problem in industrial economics and not particular to arms firms. There is an extensive qualitative literature on the corporate strategies of the large arms firms. This covers issues like the evolution of individual companies, the extent to which they specialize in military sales, the process of merger, acquisition, and divestment, the extent of internationalization, and the relative importance of demand side, government, and supply side, corporate, forces in the evolution of market structure. These all pose interesting questions, but quantitative work is complicated by modeling the processes of mergers and acquisition and entry and exit from the list, which make it difficult to identify continuous entities. There is also the problem that firms change their names, e.g., Finmeccanica was renamed Leonardo in April 2016.

SIPRI note that the same 12 companies have occupied the first 10 ranks during the past 15 years so one can do time-series analysis for those companies. Table 3 gives the data for the top 11 in 2016 and some others that also had high rankings in 2002. The ones that are excluded are as follows. Number 12 in 2016 was Huntington Ingalls Industries, from the U.S., a shipbuilder formed in 2011 as a spin-off from Northrop Grumman. Number 13 in 2016, United Aircraft Corp., Russia, did not appear on the 2002 list. It was created in 2006 by merging various Russian firms. Number 14 in 2016, Bechtel Corp., U.S., a construction company, was not on the 2002 list. Number 18 in 2016, Harris Corp., U.S., electronic systems, was number 37 in 2002. Number 19 in 2016, United
Shipbuilding Corp., Russia, established in 2007, was not on the 2002 list. Number 20 in 2016, Booz Allen Hamilton, U.S., a government services company, was number 47 in 2002.

If one looks at plots of the logarithm of arms sales for the 15 large companies, the variance over all 15 firms is fairly constant. The largest drops by individual firms were when Leidos was formed as a spin-off from Science Applications International Corp. in 2013, and the big fall in United Technology sales from 2014 to 2016 with its divestment of Sikorsky. There is clearly an element of sample selection bias in choosing to focus on companies that had high rankings in both years, but the stability at the top contrasts with the turbulence of the histogram of growth over the whole sample.

The average of the 105 correlations between these firms is 0.68 . There are 19 pairwise correlations over 0.9 and only 4 negative correlations. The four negative correlations all involve Northrop Grumman, perhaps because of the effect of the spin-off of Huntington Ingalls in 2011. Northrop Grumman's correlation with Rolls-Royce was -0.10 , with Lockheed -0.10 , with Textron -0.05 , and with United Technologies -0.03 . Northrop has the lowest average correlation, at 0.22 , and the next lowest is 0.50 for Leidos, the SAIC spin-off. Airbus has the highest average correlation, at 0.81 . Principal components, PCs, were used to examine the commonality between the performance of the firms. The first PC explains 73 percent of the variance. It weights the firms roughly equally, with loadings between 0.2988 and 0.2149 , except for Northrop which gets a weight of 0.0884 , reflecting its low correlations. 
The first two PCs explain 87 percent of the variance. The second PC weights heavily negatively on Lockheed, Mitsubishi, Rolls-Royce, and Textron and positively on Northrop and Leidos. It seems to be distinguishing between two types of companies but it is not obvious on what basis, beyond distinguishing Northrop and Leidos which have low correlations with the others. The third PC raises the cumulative proportion explained to 92 percent, but does not have an obvious interpretation.

To examine how the logarithm of the arms sales of each firm responded to the total log arms sales, 15 error correction equations were estimated. These were similar to that used above for the arms sales to military expenditure relationship. This model proved to have too many parameters for the 14 observations available, although the fit was quite high with 4 firms with adjusted $\mathrm{R}^{2}$ over 0.9 , and another 6 with over 0.8 . Boeing with an adjusted $\mathrm{R}^{2}$ at 0.47 and Northrop at 0.49 were the lowest. The average short-run effect was 1.2 and the long-run effect, calculated from the averages of the short-run coefficients, was 0.98 . The average speed of adjustment was 0.43. Although the averages look plausible, the individual estimates often do not and there was a large dispersion around the averages. For L-3, the adjustment coefficient was negative and there were 4 firms with a short-run elasticity greater than 2. There was no obvious common restricted form that looked likely to work better.

There is an element of judgment in how one links the firms. For instance Electronic Data Systems (EDS) and HP could have been (but was not) treated as continuous, as the latter had no arms sales prior to their acquisition of the former. This process of merger, acquisition, and divestment is continuing. In February 2018, General Dynamics announced it was acquiring the IT and cybersecurity group CSRA for USD9.6 billion. This would make GD+CSRA the second-largest defense IT company on 2018 revenues of about USD10 billion, after Leidos, with just over USD10 billion (and followed by Booz Allen, with around USD6 billion). This process is always political as indicated by the controversy around the proposed alliance of Fincantieri of Italy and Naval of France to create a
European "champion" in military shipbuilding.

Other questions that could be analyzed with SIPRI's time series for firms constructed from the arms industry database include the balance between military and other sales, and much greater use and comparison could be made with other sources such as the Defense News' top-100 list.

\section{Growth by country}

The analysis thus far has been for individual arms companies, but one can look at individual countries to gain some idea of the changing geographical distribution of arms production. Table 4 gives the number of firms in the top-100 list and total arms sales in 2002 and 2016 by country of ownership of the firm as given by SIPRI. Also included are the two transEuropean firms, Airbus/EADS and MBDA, although many of the national firms like BAE Systems and Leonardo are effectively multinational. BAE's U.S. subsidiary had arms sales of USD9.3 billion, almost half its total arms sales of USD22.8 billion. Real growth for the top-100, calculated using a price index which is 1 in 2016 and 0.74 in 2002, was 38 percent. The U.S. grew slightly slower, at 25 percent, so its share of the total fell, from 64 percent to 58 percent. Russian, South Korean, and Indian sales all more than doubled. In real terms, German sales dropped while trans-European sales grew, mainly because of Airbus. The Italian growth between 2002 and 2016 is largely the result of the expansion of Leonardo/Finmeccanica (although, in 2016, had rather smaller arms sales than it had in 2010-11). 


\section{Conclusion}

Given the vast amount of econometric work using SIPRI's military expenditure and arms transfer data it is surprising that there is not more quantitative work using the arms industry data. It may be that political scientists, who are interested in arms, think primarily in terms of nation states rather than firms while economists, who do think in terms of firms, are not particularly interested in arms. The data are provided as tables for each year giving the company name, rank, and data. This means that it is less convenient to get time series but the amount of work involved is not that great, as the examples above illustrate. A more serious problem for the quantitative analysis of the firm data on arm sales is how one deals with mergers and acquisitions, which reduce the number of companies, and divestments, which increase the number. Both introduce discontinuities over time. There is considerable qualitative analysis of this process, but it is not obvious how to code and model these transitions. This is less of a problem with cross-section studies that look at a moment in time but is a severe problem for time-series analysis.

Overall, our conclusion is that SIPRI's database is a valuable asset and that there is considerable scope for more formal quantitative modeling of the evolution of the structure of the arms industry, although there are some issues that need to be confronted in conducting a quantitative analysis. In particular, one needs methods of handling the implications of mergers, acquisitions, and divestments for the data. We have certainly found the data valuable and used it in a number of papers, including Smith (2013a,b) as well as Dunne and Smith (2016) and we are sure that there is scope for much greater use.

\section{Notes}

This is a revision of a paper prepared at the SIPRI Expert Workshop, 22 March 2018. We are grateful to Sam Perlo-Freeman for considerable help and to Ensar and Filiz Yesilyurt, workshop participants, and an anonymous reviewer for useful comments on earlier versions.

1. At a March 2018 workshop held at SIPRI's offices, Michael Broszka discussed various methods of combining data to get rough estimates of arms production.

2. It was suggested at the workshop that SIPRI could make more readily available the information it had on entry and exit.

3. In the description of Sources and Methods SIPRI say: "The SIPRI definition of arms sales serves as a guideline; in practice it is difficult to apply. Nor is there any good alternative, since no generally agreed standard definition exists. In some cases, the data on arms sales reflects only what a company considers to be the defence share of its total sales. In other cases, SIPRI uses the figure for the total sales of a 'defence' division, although the division may also have some unspecified civil sales. When the company does not report a sales figure for a defence division or similar entity, arms sales are sometimes estimated by SIPRI. Such estimates are based on data on contract awards, information on the company's current arms production and military services programmes, and figures provided by company officials in media or other reports. For all these reasons, the comparability of the company arms sales figures given in the Top 100 is limited."

4. We have used the publicly available dataset to allow replication. SIPRI's full dataset includes companies below the top-100 and it would be helpful if SIPRI could make this more readily available. There is also a potential problem of sample selection bias as initially large firms which grow slowly drop out of the sample and initially small firms that grow fast enter.

5. This was missing for a few companies and set at 50 percent in those cases.

6. The variance of growth rates is much larger for the smaller companies but the $t$-statistics are even larger if heteroskedasticity-robust standard errors are used.

\section{References}

Dunne, J.P., M. Garcia-Alonso, P. Levine, and R.P. Smith. 2007. "Determining the Defence industrial Base." Defence and Peace Economics. Vol. 18, No. 3, pp. 199-221. https://doi.org/10.1080/10242690600924273

Dunne, J.P. and R.P. Smith. 2016. "The Evolution of Concentration in the Arms Market." The Economics of Peace and Security Journal. Vol. 11, No. 1, pp. 12-17. https://doi.org/10.15355/epsj.11.1.12

Hartley, K. 2017. The Economics of Arms. Newcastle upon Tyne, UK: Agenda Publishing. https://doi.org/10.2307/j.ctv5cg7q6

Smith, R.P. 2013a. "The Defense Industry in an Age of Austerity." The Economics of Peace and Security Journal. Vol. 8, No. 1, pp. 18-22. https://doi.org/10.15355/epsj.8.1.18

Smith, R.P. 2013b. "The Economics of Defence in France and the UK." in Jacques Aben, et al., eds. Liber Amicorum: Hommage en l'honneur du Professeur Jacques Fontanel. Paris: L'Harmattan. Revised version published as Birkbeck Working Papers in Economics and Finance 1304.

Smith, R.P. 2017. "Military Expenditure Data: Theoretical and Empirical Considerations." Defence and Peace Economics. Vol. 28, No. 4, pp. 422-428. https://doi.org/10.1080/10242694.2016.1245823

Smith, R.P. and A. Tasiran. 2010. "Random Coefficient Models of Arms Imports." Economic Modeling. Vol. 27, pp. 1522-1528.

https://doi.org/10.1016/j.econmod.2010.07.017 